\title{
Erratum to the expression of programmed death-ligand 1 in patients with invasive breast cancer
}

\section{Editorial Office}

Gland Surgery

Correspondence to: Editorial Office. Gland Surgery. Email: editor@glandsurgery.org.

doi: $10.21037 / g s-2021-03$

View this article at: http://dx.doi.org/10.21037/gs-2021-03

Erratum to: Gland Surg 2020;9:2106-15

In the Vol 9, No 6 (December 2020) issue of Gland Surgery, the paper "The expression of programmed death-ligand 1 in patients with invasive breast cancer" by Dr. Rong Li et al. (1) was published with an error in authors' affiliation.

The first affiliation "Department of Oncology, The Affiliated Taikai Xianlin Drum Tower Hospital, Medical School of Nanjing University, Nanjing, China" in the article should be corrected as "Department of Oncology, The Affiliated Taikang Xianlin Drum Tower Hospital, Medical School of Nanjing University, Nanjing, China".

Click here to view the updated version of the article.

Open Access Statement: This is an Open Access article distributed in accordance with the Creative Commons AttributionNonCommercial-NoDerivs 4.0 International License (CC BY-NC-ND 4.0), which permits the non-commercial replication and distribution of the article with the strict proviso that no changes or edits are made and the original work is properly cited (including links to both the formal publication through the relevant DOI and the license). See: https://creativecommons.org/licenses/by-nc$\mathrm{nd} / 4.0 /$.

\section{References}

1. Meng Y, Wu H, Yao Y, et al. The expression of programmed death-ligand 1 in patients with invasive breast cancer. Gland Surg 2020;9:2106-15.

Cite this article as: Editorial Office. Erratum to the expression of programmed death-ligand 1 in patients with invasive breast cancer. Gland Surg 2021;10(4):1553. doi: 10.21037/gs-2021-03 